\title{
Konvergensi Media dan Teknologi: Implikasinya terhadap Komunikasi Pemasaran Pariwisata
}

\author{
Heri Puspito Diyah Setiyorini \\ Universitas Pendidikan Indonesia \\ hp_diyah@upi.edu
}

\begin{abstract}
This paper would give a conceptual discussion of the media convergence, technology acceptance model, and its implication on tourism marketing communication. Media convergence is the integration of multiple media, particularly conventional media with the new media. Conventional media such as a printed, audio, and audio-visual media are now integrated by the Internet technology. Thus, the information can be accessed through the personal devices. This notion affects to the way people use their leisure times, as well as, the industry do the marketing activities for tourism. Since the length of stay of tourists is decreasing, so the technology intent to assist these activities to the tourist. Hence, the paper would also discuss the tendency of the short-break tourists and the tourism business players in using the technology and its implication to the marketing communication.
\end{abstract}

Keywords- Media Convergence; Marketing Communication; Tourism Industry; Short-break Holiday

\section{Pendahuluan}

Konvergensi teknologi saat ini mengubah tatanan komunikasi massa menjadi komunikasi individu (J.O. \& Friday, 2012). Dengan kata lain, pemusatan dan penggabungan beberapa media komunikasi massa ke dalam satu perangkat yang dapat diakses oleh individu. Konvergensi juga berarti sinergitas antara teknologi komunikasi yang terpisah seperti telepo, data, dan video ke dalam system yang terintegrasi. Hal ini mengubah tatanan kehidupan keseharian manusia, yaitu pada cara berkomunikasi, melakukan proses konsumsi, bekerja, menggunakan waktu luang, dan berbagai ancaman dan peluang lain dalam masyarakat luas (J.O. \& Friday, 2012).

Demikian juga terjadi pada kegiatan pariwisata, konvergensi media, teknologi, informasi, mengubah tatanan kegiatan pada sisi permintaan dan penawaran secara dengan sangat signifikan. Wisatawan sebagai pihak yang berada pada sisi permintaan, dahulu membutuhkan waktu yang panjang untuk merencanakan perjalanan. Namun saat ini terbantukan oleh keberadaan teknologi informasi untuk memproses perjalanan dengan lebih cepat.

Media informasi melalui konvensional seperti brosur, majalah, koran, radio, dan televisi, saat ini terintegrasi dalam situs web. Bahkan, konvergensi tidak hanya menggabungkan beberapa media oleh satu pengelola industry pariwisata. Kolaborasi dalam konvergensi media komunikasi pemasaran dilakukan dengan berbagai bentuk.

Sebagai contoh, peran perantara (intermediary) dalam pemasaran pariwisata, saat ini mulai digantikan oleh perusahaan perantara yang beroperasi secara daring melalui on-line travel agent, seperti traveloka.com, agoda.com, pegipegi.com, dan lain sebagainya. Calon wisatawan akan dengan mudah merancang perjalanannya, seperti memesan tiket, membooking kamar hotel, membeli tiket pertunjukan/event, bahkan membeli paket wisata di destinasi yang dituju.

Ketika wisatawan berada di destinasi, dibantu dengan system transportasi daring seperti gojek, gocar, uber, grab, semakin memudahkan mobilitas di tempat yang dikunjungi. Berbekal peta digital dan akses melalui ponsel pintar untuk memesan kendaraan, wisatawan dapat mengunjungi destinasi wisata. Kepastian terhadap jarak dan waktu tempuh serta biaya yang akan dikeluarkan membantu wisatawan untuk mendapatkan "kepastian" ketika berada di wilayah yang asing.

Kemudahan aksesibilitas fisik dan informasi di suatu destinasi menjadi faktor pendorong seseorang untuk melakukan perjalanan wisata.

Adapun dari sisi permintaan, meningkatnya golongan ekonomi menengah menjadi pasar yang menjanjikan untuk pengembangan pariwisata. Bank Dunia mencatat bahwa 
kemajuan golongan kelas menengah meningkat dari $0 \%$ di tahun 1999 menjadi $6,5 \%$ di tahun 2011 atau setara dengan 130 juta jiwa. Bahkan perkembangannya akan terus meningkat menjadi 141 juta pada tahun 2020 (http://www.jpnn.com/news/jumlah-kelasmenengah-di-indonesia-melesat-ini-datanya).

Peluang ini dimanfaatkan oleh industry jasa untuk menangkap pasar sasaran domestik agar melakukan kegiatan wisata. Namun demikian, biasanya golongan kelas menengah adalah usia produktif yang memiliki waktu kerja yang cukup padat, sehingga membutuhkan waktu yang singkat untuk melakukan kegiatan wisata. Konsep liburan singkat (short-break holiday) dilakukan selama kurang lebih 2-3 malam sebelum seseorang kembali kepada rutinitas pekerjaannya ((Huybers, 2003). Ketika melakukan liburan singkat, biasanya seseorang membutuhkan waktu yang singkat untuk merencanakan dan mengatur perjalanannya. Maka, diasumsikan konvergensi media menjadi solusi untuk melaksanakan kegiatan liburan ini.

Kajian terhadap ketertarikan pasar dan pebisnis pariwisata dalam memanfaatkan teknologi untuk

Oleh sebab itu, maka menarik untuk dilakukan penelititan tentang konvergensi media dalam komunikasi pemasaran pariwisata serta implikasinya pada niat untuk melakukan liburan singkat.

\section{KAJIAN PUSTAKA}

A. Konsep tentang Konvergensi Media dan Komunikasi Pemasaran Pariwisata

Konvergensi teknologi adalah kecenderungan dari berbagai sistem teknologi yang berbeda berevolusi untuk menjalankan kegiatan yang sama. Konvergensi dapat diterapkan pada integrasi teknologi parsial, misalnya penggabungan suara (fitur telepon), data (dan aplikasi untuk meningkatkan produktivitas kerja), dan video untuk berinteraksi secara sinergis. Kondisi ini menurut Roger Fidler (1997) dalam Olawuyi \& Friday (2012) disebut dengan "mediamorphosis". Atau perubahan wujud media.

Saat ini kita berada pada ranah konvergensi moda komunikasi dan informasi (J.O. \& Friday, 2012) yang mengubah tatanan kehidupan manusia dalam kesehariannya, meliputi cara komunikasi, belajar, konsumsi atau bertransaksi, belajar, dan berinteraksi dengan sesama.

Lebih lanjut, (J.O. \& Friday, 2012) menyatakan bahwa konvergensi menyatukan konten yang berbeda (data, audio, suara, dan video) untuk dapat disimpan dalam format digital untuk disampaikan melalui berbagai variasi teknologi seperti komputer, ponsel, dan televisi dan dapat diakses dengan berbagai platform.

Ada dua definisi besar dari konvergensi yaitu konvergensi teknologi dan media atau konten. Konvergensi teknologi terjadi melalui berbagai produk yang menyatukan berbagai bentuk dalam satu produk dengan mengandung segala keuntungan dan manfaatnya. Konvergensi media merupakan "removal of entry barriers across the IT, telecom, media and consumer electronics industries, creating one large 'converged' industry" atau upaya menghilangkan hambatan untuk masuk karena adanya teknologi informasi, telekomunikasi, media, dan industri elektronik, sehingga menciptakan satu industri yang terintegrasi. Hal ini mengindikasikan adanya kemudahan akses informasi yang diberikan kepada pengguna melalui berbagai media. ((Olawuyi \& Friday, 2012)

Selanjutnya Schneider (2012) menyatakan bahwa konvergensi memiliki kekuatan yang dasyat dalam dunia pemasaran dan penjualan pariwisata. Saat ini, wisatawan dapat mengendalikan kepuasan berwisata melalui kemajuan teknologi dan akses informasi yang cepat.

Menurut Forrester (dalam Sneider, 2012) suatu perusahaan harus merekonfigurasi sumberdaya dan kapabilitas untuk mengakomodasi perubahan teknologi yang digunakan oleh konsumen. Perilaku konsumen mengalami perubahan karena adanya kemajuan teknologi ini. Konsumen saat ini memiliki tingkat literasi yang tinggi terhadap media (Livingstone et al., 2008). Adapun yang disebut dengan literasi media adalah kemampuan untuk mengakses, menganalisis, mengevaluasi, dan mengkomunikasian pesan dalam berbagai bentuk (Aufderheide, 1993; Christ \& Potter, 1998 dalam Livingstone et al., 2008)).

\section{B. Technology Acceptance Theories}

Konsep tentang konvergensi media dan komunikasi pemasaran menunjukan peranan wisatawan maupun pebisnis untuk mengadaptasi teknologi dalam aktivitas pariwisata. Wisatawan mengadaptasi teknologi untuk mencari informasi, transaksi, dan berbagi pengalaman berwisata. Pebisnis melakukan adaptasi terhadap teknologi untuk dapat menjangkau pasar dan meningkatkan performa bisnisnya.

Adaptasi terhadap teknologi baru dikembangkan oleh Rogers (1962) pada awal tahun 1960an, dengan mengemukakan teori difusi inovasi, yang berbasis sosiologi. Ostlund 
(1974) dan G.C. Moore dan Benbasat (1991) mengembangkan model Roger dengan menambahkan karakteristik pemahaman resiko untuk mengkaji akseptabilitas teknologi.

Terkait dengan peran difusi teknologi dengan perilaku manusia, pada awal tahun 1970-an, Fishbein dan Ajzen (1975) mengembangkan teori tindakan beralasan (theory of reasoned action/TRA). Berbeda dengan Rogers (1962) konsep yang dikembangkan oleh Fishbein dan Ajzen (1975) lebih menekankan teori ini pada sudut pandang psikologi.

Selanjutnyam Ajzen mengembangkan teori tentang perilaku terencana (theory of planned behaviour/TPB) yang didasari oleh perenungan/pemaknaan mendalam tentang kendali perilaku yang dirasakan (perceived behavioral control). TPB mengacu pada tingkat kemudahan/kesulitan dari seseorang untuk mempercayai/meyakini tindakan/perilaku yang akan dijalankan/kerjakan. Adapun komponen dari TPB adalah subjective norm, attitude, dan perceived quality sebagai antesendantnya. TPB telah digunakan secara luas untuk mengkaji perilaku dalam konteks sosiologi, psikologi, psikologi sosial, dan pemasaran, juga, akseptabilitas terhadap teknologi (Ajzen, 1991; Baker, Al-Gahtani, \& Hubona, 2007).

Davis (1986) pada era 1980-an, mengembangkan model akseptabilitas teknologi (Technology Acceptance Model /TAM) untuk mengkaji bagaimana penggunaan (usage) dan akseptabilitas teknologi baru dalam organisasi. Dimensi dalam model ini adalah persepsi terhadap manfaat yang dirasakan (Perceived Usefulness / PU), persepsi terhadap kemudahan penggunaan (Perceived Ease of Use / PEOU), niat untuk menggunakan (intention to use), dan penguunaan sistem secara aktual (actual system usage).

Terkait model akseptabilitas teori dan teori awal tentang difusi teknologi, Black, Lockett, Winklhofer, and Ennew (2001) mengembangkan teori difusi inovasi sebagai model yang lebih komprehensif untuk menerima teknologi dengan menambahkan dua karakteristik, yaitu issue dalam masyarakat (societal issuess) dan rasa untuk menerima perubahan teknologi tersebut karena tidak dapat dihindari (sense of fatalism).

Vankatesh dan Davis (2000) juga mengembangkan konsep TAM menjadi dengan menambahkan konstruk / komponen baru, yaitu subjective norm. Dalam perkembangannya, konsep ini juga dikaji untuk memahami penggunaan teknologi yang berbeda termasuk didalamnya kajian teknologi sebagai sistem pendukung keputusan pemasaran (marketing decision support system) (Wober \& Gretzel, 2000).

Selanjutnya, berdasarkan pada teori psikologi dan sosiologi, Venkatesh et al. (2003) membandingkan persamaan dan perbedaan antara berbagai model dan konstruk menjadi sebuah kombinasi yang dikenal dengan unified theory of acceptance and use of technology (UTAUT). Dimensi yang membentuk UTAUT ada 4 hal, yaitu Performance Expectancy (PE), Effort Expectancy (EE), Social Influence (SI), dan Facilitating Conditions (FC). Ada pula empat moderator dalam UTAUT, yaitu usia, gender, pengalaman, dan menerima dengan sukarela (age, gender, experience, and voluntariness).

\section{PEMBAHASAN}

A. Penelitian tentang Akseptabilitas Teknologi di Bidang Pariwisata

Sejak tahun 1980-an, teknologi informasi telah mentransformasi pariwisata secara global dan radikal (Buhalis \& Law, 2008; Ho \& Lee, 2007; Lai 2013). Oleh sebab itu, popularitas teknologi informasi telah mendorong para peneliti untuk mengkaji perkembangan sistem informasi dalam pariwisata (Martín \& Herrero, 2011; Lai, 2013). Namun demikian, masih sedikit studi yang dilakukan untuk meneliti perilaku dalam menerima teknologi pariwisata (T. T. Kim, Lee, \& Law, 2008).

Kajian terhadap akseptabilitas teknologi dalam pariwisata dapat diklasifikasikan dalam dua kategori (Lai, 2013), yaitu: (1) perilaku karyawan/SDM pada institusi dan industri pariwisata dalam menerima teknologi; dan (2) perilaku wisatawan dalam menerima teknologi tersebut.

Berikut disampaikan beberapa penelitian terkait dengan penerapan konsep TAM yang dihimpun dari LAI (2013) sebagai berikut:

1. Penerapan Konsep TAM pada perilaku karyawan pada institusi dan industri pariwisata

Beberapa penelitian pada kemampuan sumber daya manusia untuk menerapkan sistem pengambilan keputusan pemasaran (Wober \& Gretzel, 2000), menggunakan computerized reservation systems $(H$. Y. Lee, Kim, \& Lee, 2006), mengimplementasikan Internet marketing (El-Gohary, 2012; D. Y. Kim, 2009), keterampilan menggunakan hotel information systems (Huh, Kim, \& Law, 2009; T. T. Kim, Suh, Lee, \& Choi, 2010), menggunakan teknologi inovatif untuk sistem teknologi dan informasi (Cheng \& Cho, 2011), dan 
pembelajaran melalui ponsel / m-learning $(S$. $J$. Kim \& Kizildag, 2011).

2. Penerapan Konsep TAM pada perilaku wisatawan dalam menerima teknologi pariwisata

Lebih dari $40 \%$ dari wisatawan mancanegara saat ini memiliki telepon seluler pintar yang memiliki akses internet (ITB Berlin, 2010; Lai 2013). Ponsel pintar memiliki kapabilitas input yang beragam, ukuran layar yang lebar, akses ineternet, dan fungsi penunjuk lokasi (location awareness functions ) (Want, 2009; Lai 2013). Hal ini membantu wisatawan dalam mengakses informasi untuk merencanakan perjalanan serta mendukung mobilitas selama berwisata.

Hal ini sejalan dengan beberapa penelitian yang saat ini difokuskan pada penggunaan situs web untuk mencari informasi (Law, Qi, \& Buhalis, 2010; Yeung \& Law, 2006; Lai 2013) dan melakukan pembelian produk pariwisata secara daring (Law \& Hsu, 2006; Martín \& Herrero, 2011; Phelan, Christodoulidou, Countryman, \& Kistner, 2011;Lai 2013).

Manfaat ponsel pinter semakin penting karena dapat menyangga ribuan aplikasi seluler (D. Wang, Park, \& Fesenmaier, 2012; Lai, 2013) yang juga mendukung kemudahan wisatawan.

3. Perubahan Demand Konsep tentang Liburan Singkat (short-break holiday)

Sustainable Tourism Cooperative Research Centre (STCRC) mendefinisikan liburan singkat atau (short-break holiday) sebagai perjalanan yang ditujukan bukan untuk bekerja (nonbusiness trip) dengan durasi perjalanan antara 1 - 4 malam di luar dari tempat tinggalnya (Murphy, Niininen, \& Sanders, 2010). Murphy, et al (2010) juga menyatakan bahwa destinasi yang dikunjungi oleh wisatawan yang mengadakan liburan singkat, yang sebelumnya disebut dengan wisatawan "overnight" atau "intransit" biasanya menyediakan event atau banyak atraksi wisata. Kegiatan yang dilakukan bermacam-macam, mulai dari terlibat aktif dalam event atau hanya berkunjung untuk melihat-lihat atraksi wisata di destinasi. Uysal dan McDonald's (1989) menyarankan untuk membangun indeks perjalan untuk membedakan wisatawan yang aktif dan yang pasif dalam melakukan liburan singkatnya.

Oleh sebab itu, penekanan pada teknologi informasi dan media yang dapat mendukung wisatawan agar dapat mengambil keputusan dengan cepat menjadi suatu keniscayaan.

\section{KESIMPULAN}

Simpulan dari beberapa paparan yang disampaikan adalah sebagai berikut. Konvergensi media dan teknologi mengubah tatanan pemasaran pariwisata yang meliputi perilaku wisatawan maupun pebisnis yang berkecimpung didalamnya. Adaptabilitas dalam penggunaan teknologi bagi wisatawan dan pebisnis pariwisata pada dasarnya didorong oleh persepsi tentang manfaat dan kemudahan penggunaan teknologi yang mendorong penggunaan teknologi tersebut secara aktual. Fenomena terhadap perubahan perilaku wisatawan dan pebisnis pariwisata sebagai dampak dari adanya konvergensi media dan teknologi perlu dikaji lebih lanjut.

\section{DAFTAR RUJUKAN}

Ajzen, I. (1985). From intentions to actions: A theory of planned behavior. In J. Kuhl \& J. Beckmann (Eds.), Action control: From cognition to behavior (pp. 11-39). Heilderberg, Germany: Springer.

Aufderheide, P. (1993). Media Literacy: A report of the national leadership conference on media literacy. Aspen, CO.: Aspen Institute. S[E.

Baker, E. W., Al-Gahtani, S. S., \& Hubona, G. S. (2007). The effects of gender and age on new technology implementation in a developing country: Testing the theory of planned behavior (TPB). Information Technology \& People, 20 , 352-375.

Black, N. J., Lockett, A., Winklhofer, H., \& Ennew, C. (2001). The adoption of internet financial services: A qualitative study. International Journal of Retail \& Distribution Management, 29 , 390-398.

Buhalis, D., \& Law, R. (2008). Progress in information technology and tourism manage -ment: 20 Years on and 10 years after the internet-The state of eTourism research. Tourism Management, 29 , 609623.

Cheng, S., \& Cho, V. (2011). An integrated model of employees' behavioral intention toward innovative information and communication technologies in travel agencies. Journal of Hospitality \& Tourism Research, 35 , 488-510.

Christ, W. G., \& Potter, W.J. (1998). Media literacy: Symposium. Journal of Communication, 48(1).

Davis, F. D. (1986). A technology acceptance model for empirically testing new enduser information systems: Theory and results (Unpublished doctoral dissertation). Sloan School of 
Management, Massachusetts Institute of Technology, Amherst.

El-Gohary, H. (2012). Factors affecting emarketing adoption and implementation in tourism firms: An empirical investigation of Egyptian small tourism organisations. Tourism Management, 33 , 1256-1269.

Fishbein, M., \& Ajzen, I. (1975). Belief, attitude, intention, and behavior: An introduc -tion to theory and research. Reading, MA: Addison-Wesley.

Huh, H. J., Kim, T. T., \& Law, R. (2009). A comparison of competing theoretical mod -els for understanding acceptance behavior of information systems in upscale hotels. International Journal of Hospitality Management, 28 , 121-134.

Ho, C. I., \& Lee, Y. L. (2007). The development of an e-travel service quality scale. Tourism Management, 28 , 1434-1449.

Huybers, T. (2003). Modelling short-break holiday destination choices. Tourism Economics, 9(4), 389-405.

J.O., O., \& Friday, M. (2012). Technological Convergence. Science Journal of Physics, 2012. https://doi.org/10.1007/BF02786367

Kim, T. T., Lee, J. H., \& Law, R. (2008). An empirical examination of the acceptance behaviour of hotel front office systems: An extended technology acceptance model. Tourism Management, 29 , 500513.

Kim, T. T., Suh, Y. K., Lee, G., \& Choi, B. G. (2010). Modelling roles of tasktechnology fit and self-efficacy in hotel employees' usage behaviors of hotel information sys -tems. International Journal of Tourism Research, 12, 709725.

Kim, S. J., \& Kizildag, M. (2011). M-learning: Next generation hotel training system. Journal of Hospitality and Tourism Technology, 2 , 6-33.

Lai, I. K. W. (2013). Traveler Acceptance of an App-Based Mobile Tour Guide. Journal of Hospitality \& Tourism Research, $X X(\mathrm{X})$, 1-32. https://doi.org/10.1177/10963480134915 96

Law, R., Qi, S., \& Buhalis, D. (2010). Progress in tourism management: A review of website evaluation in tourism research. Tourism Management, 31 , 297-313.

Law, R., \& Hsu, C. H. C. (2006). Importance of hotel website dimensions and attri -butes: Perceptions of online browsers and online purchasers. Journal of Hospitality \& Tourism Research, 30 , 295-312.

Lee, H. Y., Kim, W. G., \& Lee, Y. K. (2006). Testing the determinants of computerized reservation system users' intention to use via a structure equation model.

Livingstone, S., Van Couvering, E., Thumin, N., Coiro, J., Knobel, M., Lankshear, C., \& Leu, D. (2008). Converging traditions of research on media and information literacies. Handbook of Research on New Literacies, 103-132.

Martín, H. S., \& Herrero, A. (2011). Influence of the user's psychological factors on the online purchase intention in rural tourism: Integrating innovativeness to the UTAUT framework. Tourism Management, 33 , 341-350.

Murphy, P., Niininen, O., \& Sanders, D. (2010). Short-Break Holidays - A Competitive Destination Strategy. Australia: CRC for Sustainable Tourism Pty Ltd. Retrieved February 15, 2014, from http://www.crctourism.com.au/wms/uplo ad/resources/110019\%20Murphy\%20Sho rt\%20Breaks\%20WEB\%20(1).pdf

Moore, G. C., \& Benbasat, I. (1991). Development of an instrument to measure the perceptions of adopting an information technology innovation. Information Systems Research, 2 , 192-222.

Olawuyi, J., \& Friday, M. (2012). Technological Convergence. Science Journal of Physics, 1-5. Retrieved February 14, 2014, from http://www.sjpub.org/sjp/sjp-221.pdf

Ostlund, L. E. (1974). Perceived innovation attributes as predictors of innovativeness. Journal of Consumer Research, 1 (2), 2329.

Park, J. (2015). The Impact of Different Types of Media on Tourists' Behavioral Intentions.

Phelan, K. V., Christodoulidou, N., Countryman, C. C., \& Kistner, L. J. (2011). To book or not to book: The role of hotel web site heuristics. Journal of Services Marketing , 25 , 134-148.

Rogers, E. M. (1962). Diffusion of innovations (1st ed.). New York, NY: Free Press

Schenk, T., Loffler, G., \& Rauh, J. (2007). Agent-Based Simulation of Consumer Behaviour in Grocery Shopping on Regional Level. Journal of Business Research, 60(8), 894-903.

Schneider, T. (2012). Converging on Success: Best Practices for Managing Convergence in Hospitality Sales, Marketing, and 
Revenue Optimization. Hospitality Sales \& Marketing Association International, 19. Retrieved February 15, 2014, from http://sabrehospitality.com/pdf/2012--

Convergence.PDF

Tay, N., \& Lusch, R.F. (2005). A preliminary test of Hunt's General Theory of Competition: using artificial agents to study complex and ill-defined environment. Journal Business Research, 58(9), 1155-1168.

Uysal, M., \& McDonald, C. (1989). Visitor Segmentation by Trip Index. Journal of Travel Research, 27(3), 38-42.

Van Middelkoop, M., Borgers, A., \& Timmermans, H. (2003). Inducing Heuristic Principles of TourisT Choice of Travel Mode: a Rule-Based Approach. Journal of Travel Research, 42(1), 75-83.

Venkatesh, V., \& Davis, F. D. (2000). A theoretical extension of the technology accep -tance model: Four longitudinal field studies. Management Science, 45, 186-204.
Venkatesh, V., Morris, M. G., Davis, G. B., \& Davis, F. D. (2003). User acceptance of information technology: Toward a unified view. MIS Quarterly, 7 , 425-478.

Want, R. (2009). When cell phones become computers. Pervasive Computing, IEEE , 8 (2), 2-5.

Wober, K., \& Gretzel, U. (2000). Tourism managers' adoption of marketing decision support systems. Journal of Travel Research, 39 , 172-181.

Wang, D., Park, S., \& Fesenmaier, D. R. (2012). The role of smartphones in mediating the touristic experience. Journal of Travel Research, 51, 371-387.

Yeung, T. A., \& Law, R. (2006). Evaluation of usability: A study of hotel web sites in Hong Kong. Journal of Hospitality \& Tourism Research, 30 , 452-473

http://www.jpnn.com/news/jumlah-kelasmenengah-di-indonesia-melesat-inidatanya 